\title{
Framing Librarianship in the Academy: An Analysis Using Bolman and Deal's Model of Organizations
}

\section{Rachel A. Fleming-May and Kimberly Douglass}

\begin{abstract}
Since the earliest days of the profession, academic librarians have attempted to reconcile their status within the academy. This project takes a new approach to this effort by using Lee Bolman and Terrence Deal's "Four Frames" model to analyze the issues. To more closely examine the dynamics, tensions, and implications associated with librarians' professional status within the academy, we discuss the role of the academic librarian in the context of each of Bolman and Deal's frames: Structural, Human Resource, Political, and Symbolic. In this discussion, we demonstrate that librarians are positioned to address human resource (as defined by Bolman and Deal), political, and symbolic factors contributing to their status within the academy. Also, while we establish that the relationship between library faculty and disciplinary faculty plays a role in library faculty status, we conclude that library faculty status is constructed by a number of forces. We further conclude that many of the political and symbolic conditions experienced by librarians are rooted in structural and human resource factors controlled by upper-level administration in both libraries and the universities.
\end{abstract}

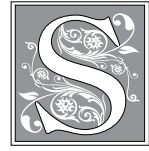

ince the earliest days of the profession, academic librarians have struggled to reconcile their status within the academy. Special attention has been afforded to concerns about the appropriateness of faculty status and rank for academic librarians. As early as the 1911 Annual Meeting of the American Library Association, W.E. Henry presented the "revolutionary" idea that "the librarian or head of the staff should have the rank and pay of a professor," and assistant librarians should also be afforded academic rank. ${ }^{1}$ The rationale Henry presented in support of this edict, that "librarianship is a learned profession" whose members should be "respected as educators by the faculty, not merely for the satisfaction of the staff but for the good of the library," is essentially the same as that presented today. ${ }^{2}$ Nearly 100 years later, Catherine Coker, Wyoma vanDuinkerken, and Stephen Bales argue that, because academic librarians' contributions to college teaching and service are "on par with teaching faculty," they are deserving of faculty status and privileges. ${ }^{3}$ The authors

Rachel A. Fleming-May and Kimberly Douglass are Assistant Professors in the School of Information Sciences at the University of Tennessee; email:rf-m@utk.edu, kdougla2@utk.edu. (C)2014 Jingfeng Xia and Minglu Wang, Attribution-NonCommercial (http://creativecommons.org/licenses/by-nc/3.0/) CC BY-NC 
present a comprehensive overview of the responsibilities and qualities bolstering the argument for academic librarians' classification as faculty, including librarians' instructional responsibilities, ongoing professional development efforts, contributions to LIS and disciplinary research, and the need for academic freedom-related protections afforded to faculty members.

The Association of College and Research Libraries (ACRL) takes the official position that academic librarians should hold faculty status. In 1972 the ACRL partnered with the American Association of University Professors (AAUP) and the Association of American Colleges (now the Association of American Colleges and Universities) to release a Joint Statement on Faculty Status of College and University Librarians. ${ }^{4}$ The statement, most recently revised and approved in October of 2012, outlines the rationale for awarding librarians faculty status. The core assertion of the ACRL/AAUP Statement is that credentials and skill sets are qualifications, but the "function of the librarian as participant in the processes of teaching, research, and service is the essential criterion of faculty status." ${ }^{5}$ Despite the reaffirmation and longevity of the statement (in different iterations), however, the nature of librarians' professional status, especially in researchoriented universities, remains a popular topic in the scholarly and professional literature.

It is interesting to note that there has been very little discussion in the literature regarding academic librarians' relationship with administrators or professional staff at their institution. In fact, past discussions of academic librarians' professional status tended to focus on the perceived tension between the academic librarians' struggles to be seen as colleagues and equals and the disciplinary faculty's denial of that recognition. In reality, however, the responsibility for academic librarians' status is much more diffuse. If reconciliation of a variety of is- sues related to librarians' status is to occur for librarians and the academy in general, we must examine the dynamics that call academic librarians' status into question from a new, more complete perspective.

\section{Framing Academic Librarianship}

To more closely examine the dynamics, tensions, and implications associated with librarians' roles within the academy, we will discuss the role of the academic librarian using Lee Bolman and Terrence Deal's "Four Frames" model. Bolman and Deal's approach provides a mechanism for exploring these dynamics from four different perspectives, resulting in structural, political, human resourcerelated, and symbolic explanations for challenges facing organizations. ${ }^{6}$ As this paper adds to the growing list of scholarly articles and books that demonstrate the conceptual strength of Bolman and Deal's framework, it also contributes to the body of literature that discusses librarians' role and status in the academy. Perhaps most significantly, it expands the discussion about the professional status of academic librarians into domains beyond the tensions between disciplinary ${ }^{7}$ and library faculty. By looking at the issues through each of the four frames, we gain a range of perspectives that is broad enough to encapsulate the plurality of forces at work while developing possible steps toward clarifying librarians' contributions to the academic enterprise.

Bolman and Deal's model has been applied in $\mathrm{K}-12$ and higher education settings, as well as such organizational settings as a newsroom, state extension agency, automotive manufacturers, and religious institutions. ${ }^{8}$ While Bolman and Deal designed their framework to address the needs of individual organizations, it is elastic enough to accommodate an entire community such as higher education, as evidenced by its application in the Harvard/ACRL Leadership Institute for Academic Librarians. In the LIS literature, the model has been used to examine library organizations but has not yet been used to 
explore the tensions experienced between librarians and the academy. ${ }^{9}$

\section{Structural Frame}

Bolman and Deal's Structural frame speaks to the way organizations regulate themselves. This view is highly quantifiable because it provides an impersonal accounting of organizational assets: person power, skill levels, capital, chairs, branches, standard operating procedures, goals, and so on. Bolman and Deal built this frame upon two tensions: how work is assigned, and how those assignments then work together to fulfill the goals of the organization. ${ }^{10}$ Bolman and Deal use Mintzberg's "Fives" model of organizations as a jumping-off point. In this view, the structure of an organization consists of five elements:

1. The operating core: is composed of people who perform essential work;

2. The administrative component: is composed of people who supervise, coordinate, control, and provide resources for operators;

3. The strategic apex: is composed of people who track current developments in the environment, determine the mission, and shape the grand design;

4. The technostructure: is composed of specialists, technicians, and analysts who standardize, measure, and inspect outputs and procedures; and

5. Support staff: is composed of people who perform tasks that support or facilitate the work of others throughout the organization. ${ }^{11}$

Depending upon the configuration of an organization's "fives," an organization can be classified a number of ways:

a. Simple Structure, in which the strategic apex exerts control;

b. Machine Bureaucracy, in which basic, standardized tasks take priority in the organization's operations; c. Divisionalized Form, in which middle managers of individual units assume control of their respective tasks and staff;

d. Adhocracy, in which expertise is recognized among members, regardless of status;

e. Professional Bureaucracy, in which members of the operating core wrest control away from members of the strategic apex to operate autonomously. ${ }^{12}$

A simple explanation of how libraries figure into the larger structure of the academic institution is telling. According to Bolman and Deal, academic institutions typically operate as what Mintzberg labels a "professional bureaucracy." ${ }^{13} \mathrm{At}$ their organizational apexes, colleges and universities have teams of administrators who develop strategy, while the large operating core of disciplinary faculty exercise a great deal of autonomy in the absence of a strong contingent of middle managers and consistent standardizing features. ${ }^{14}$

While the label of professional bureaucracy is certainly apt for academic colleges and departments, academic libraries are structured somewhat differently. Academic libraries more closely resemble Mintzberg's description of the "machine bureaucracy" in which roles are designated by work assignment, middle management is more robust, and decision making and communication tend to be hierarchical. ${ }^{15}$ Unlike the larger academic institution, libraries have large technostructures and strong apexes. Within the machine bureaucracy of the academic library, librarians are part of the operating core of the organization. In this model, librarians occupy roles that differ significantly from those of disciplinary faculty in the professional bureaucracy model and more closely resemble those of staff who provide technical support for the work of the organization. While disciplinary faculty are afforded a great deal of autonomy within their organizational units, librarians - even those with 
faculty status - are constrained by the operational needs of the library.

The professional bureaucracy imposes a different type of constraint upon academic librarians than it does on disciplinary faculty. As support staff, they "exist... as machine bureaucratic constellations within the Professional Bureaucracy."16 The role of support staff in a professional bureaucracy is largely to "carry out the simpler, more routine work and to back-up the high-priced professionals in general," filling roles defined by others. ${ }^{17}$

The emphasis of the Structural frame is on rules, procedures, and efficiency, all of which are valued in academic libraries. Academic departments, however, function with a dramatically different set of values, including inquiry, flexibility, and autonomy. According to George Kuh and Elizabeth J. Whitt, individual autonomy is one of the most prized (organizing) concepts of academia, as disciplinary faculty believe "freedom is necessary to advance learning." ${ }^{18}$ Autonomy is so important to disciplinary faculty that they have created mechanisms such as peer review, tenure, and shared governance to facilitate and protect their freedom.

In their study of the disconnect between library and disciplinary faculty, Lars Christiansen, Mindy Stombler, and Lyn Thaxton identified a number of factors that they treat as cultural, but we will consider through the Structural lens. Highlighting the divergent mindsets of librarians and disciplinary faculty, the authors identified what they call the "culture of collaboration" evident in academic librarians' commitment to "the ultimate purpose of assisting students in their educational pursuits." 19 While this commitment manifests in organizational settings, it reflects larger professional standards such as those put forth by the Association of College and Research Libraries, which is itself a separate and external structural agent.

Disciplinary faculty at research-oriented universities, on the other hand, are required to produce research, typically solitary work over which they maintain a high degree of control. In turn, university administrators demonstrate that they value the work of disciplinary faculty by supporting it through travel funds, research awards, and other types of recognition. In these institutions, administrators and colleagues reward "productive" (that is, active in research and publication) disciplinary faculty with tenure and promotion. Also, the higher education "industry" is structured with a finite number of high risk/high reward positions for which there are many qualified applicants. The rewards for disciplinary faculty, such as intellectual and other freedoms, offset the risk of dismissal from service for failing to meet expected levels of research productivity. Although academic librarians with faculty status must also go through the process of being tenured, this requirement only applies to about half of the academic library positions in the United States; an academic librarian who is unsuccessful in this endeavor can move to an institution that does not impose this constraint on its librarians. While there are positions available for disciplinary faculty who find themselves disinclined to conduct and publish research, positions that emphasize disciplinary faculty teaching over research tend to be concentrated in smaller institutions with fewer students and faculty. Positions for disciplinary faculty at larger research-focused institutions constitute nearly half of all faculty positions in the United States. ${ }^{20}$ Faculty positions for librarians, on the other hand, are not exclusive to large, researchoriented institutions. In fact, some of the most prominent research institutions in the United States employ librarians in nonfaculty positions. ${ }^{21}$

Even when an institution's academic librarians have faculty status, the divergent structural constraints experienced by academic library faculty and disciplinary faculty are reiterated-literally-in campus structures, as there is a "physical and temporal separation" of library and disciplinary faculty. ${ }^{22}$ This separation is 
facilitated in part by the flexible schedules and workspaces disciplinary faculty enjoy and is exacerbated by electronic access to information, which makes it much less vital that disciplinary faculty visit the brick-and-mortar library to conduct research. Christiansen, et al., also point to librarians' relatively centralized work environment (as opposed to disciplinary faculty's distribution around campus and beyond), as contributing to this divergence.

The academic librarian's professional status is firmly embedded in the structures of universities and university libraries. A priori to physical separations between academic library faculty and disciplinary faculty or to other structural arrangements, is the distribution of financial resources. While budgets constrain goals and objectives, they also signal the institution's priorities as disparities in compensation demonstrate the value an institution places on one type of human labor relative to another. Salary equity is an issue for academic librarians with faculty status. Paul Wyss cites several studies that have demonstrated over the years that faculty academic librarians do not earn equivalent salaries to those of disciplinary faculty of the same rank. ${ }^{23}$ The disparity of treatment, fair or not, between librarians with faculty status and disciplinary faculty is embedded in the structure of academic institutions. Of course, employee remuneration also has major implications from a human resources perspective.

\section{Human Resource Frame}

The Human Resource frame provides an interesting view of the interaction between academic librarians and the academy. Unlike the Structural frame, which emphasizes the needs of the organization over those of the individual, the Human Resource frame reflects the premise that "organizations that meet basic human needs will work better than those that do not." ${ }^{24}$ The Human Resource frame suggests that an ideal institution is one in which there is a mutually beneficial "fit" between the employee and the organization, which can manifest in a number of ways. The most fundamental metric of this "fit" is the articulation and implementation of "a shared philosophy and strategy for managing people." 25

A shared understanding of how people should behave in the institution and how the institution should treat its employees helps manage expectations on both sides. In the academic context, we might associate this mutuality with collegiality or encouragement from "a community of scholars that provides mutual support." ${ }^{26}$ In the Human Resource frame, a "progressive approach," which should be captured in a shared philosophy, directs the institution to "hire the right people, keep them, invest in them, empower them, and promote diversity." 27 Administrators who tend to view organizational problems through the Human Resource lens are first concerned with addressing this employee-organization match by "adjust[ing] the organization to fit people-or [adjusting] the people to fit the organization." ${ }^{28}$ Members of the organization might change to suit the institution's needs, while the organization itself can adapt to better serve the needs of its members. Typically, individuals adjust to the larger organization by enhancing their skills or aptitudes, while organizations may demonstrate responsiveness to employees' needs by offering flexible scheduling or support for continued education or training. Obviously, meeting an employee's need to be compensated fairly for her or his work is an essential aspect of the institutional response. In the Human Resource frame, mutuality of fit is essential, and explanations for organizational breakdowns reveal either the absence of a shared philosophy or the absence of a sincere effort to act according to that philosophy. Failure to do so can lead support staff to feel that "there is no democracy, only the oligarchy of the professionals." 29

If we consider the role of academic librarians through the Human Resource 
frame, we can see ample cause for confusion. Perhaps the most important contributing factor is that, while disciplinary faculty roles and values have been fairly consistent over centuries, academic librarians' status, qualifications, and responsibilities have changed both dramatically and regularly over time. The lack of consensus on the meaning and value of librarianship in academic institutions is also a likely contributor to the disparate treatment of librarians with faculty status from institution to institution.

Academic libraries have only been staffed by professional librarians since around the turn of the 20th century. In the early 1900s, the head librarian was usually not a trained librarian but an academic scholar who typically lacked experience or training related to the work of librarianship. Orvin Lee Shiflett describes the tenure of Ernest D. Burton, Director of the University of Chicago's library from 1910 until 1925. During this period, Burton maintained his position as Chairman of the Department of New Testament Theology. He left much of the business of the library to his associate director, James Christian Meinich Hanson, previously a cataloger at the Library of Congress. ${ }^{30}$ According to Mary Biggs, Burton maintained a good relationship with the disciplinary faculty while Hanson fought with the disciplinary faculty over implementing basic principles for organizing the collection. Despite Hanson's having largely shouldered the burden of running the library during Burton's tenure as director, when the time came to appoint Burton's successor, the university administration passed Hanson over in favor of another nonlibrarian academic. ${ }^{31}$ As the MLS degree gained prominence and degreed librarians gradually assumed leadership positions, library and disciplinary faculty "evolved into quite different creatures, each insistent upon professional autonomy, stubbornly holding sometimes disparate visions of the library's mission and communicating very little with each other." ${ }^{32}$

\section{Academic Librarians: Professional Staff or Faculty?}

The professional classification of academic librarians has significant implications in the Human Resource frame. Jean Major made the distinction between the respective frameworks for the occupations of librarian and academic scholar. According to Major, librarians conduct themselves as members of a "professional" occupation, characterized by formalized training, an established set of credentials, and a code of ethics. Most significant, Major says, is the emphasis professionals place on "delivery of expert services for a client" and the professional/client relationship. On the other hand, disciplinary faculty operate within the framework of collegiality, in which peers, rather than clients, are considered arbiters of the quality of scholarly work. ${ }^{33}$

More recent studies of disciplinary faculty at institutions where librarians also have faculty status demonstrate that many disciplinary faculty still view librarians as "professionals" or staff members whose primary responsibility is service rather than education and research, which disciplinary faculty consider their domain. ${ }^{34}$ The fact that academic libraries also employ a high proportion of nonprofessional staff people, some of whom appear to do the same type of work as librarians, likely contributes to this viewpoint. In fact, several studies have found that academic library users have difficulty discerning between librarians and support staff. ${ }^{35}$ According to Scott Walter, studies of disciplinary faculty "suggest that the academic library profession is poorly understood by those outside it." ${ }^{36}$ Exacerbating the confusion is the fact that there is no consistent status system in American academic libraries. ${ }^{37}$ If a new member of a university's disciplinary faculty conducted her graduate work at a school that does not award faculty status to its librarians, why would she assume that the librarians at her new place of employment are members of the faculty? 
Rachel Applegate identified a number of issues at play in the discussion of librarian status. One of the key notions she deconstructs is the idea that institutions whose librarians have faculty status find recruitment and retention of librarians easier to accomplish. Upon review of the empirical literature on the topic, Applegate stated that, while the paucity of relevant literature made it difficult to draw conclusions regarding faculty librarians' job satisfaction versus that of nonfaculty academic librarians, librarians with faculty status may be less satisfied in key areas. ${ }^{38}$ Bruce Kingma and Gillian M. McCombs cautioned that librarians with faculty status may be less productive in the areas traditionally associated with academic librarianship because their attention is necessarily diverted to other functions inside the academy. ${ }^{39}$

Also of concern is the possibility of faculty academic librarians being consigned to what Danielle Hoggan terms "nominal" faculty status. In such cases, librarians are conferred the responsibilities of a faculty member, such as the need to devote significant time to research and publishing, while being denied most of the benefits, such as eligibility for sabbaticals and research funding. ${ }^{40}$ More recently, Corey Johnson and Elizabeth Blakesley Lindsay surveyed public services librarians at Association for Research Libraries (ARL) member institutions to explore the duties typically assigned to that type of position and respondents' satisfaction with each. Their findings led them to call attention to a "notable disconnect among personal satisfaction, service impact on users, what librarians think matters to their administrators, and what is required of them for tenure." ${ }^{41}$

Christiansen, et al. identified a number of human resource issues related to librarians' faculty status, many of which stem from differences in the ways that library and faculty work are structured. While disciplinary faculty are afforded a high degree of autonomy, librarians' comings and goings are much more closely moni- tored. Even librarians with faculty status usually work 40-hour weeks, year round. This is largely due to the service function of the library-staff must be present to assist patrons and make materials available. Most significantly, Christiansen et al. observe that, because disciplinary faculty typically outnumber librarians on any given campus, they are more likely to have leadership of campus committees and governance. ${ }^{42}$ Walter concurs with this point, adding that "a lack of understanding across campus of the academic librarian's professional role and responsibilities can have significant implications for issues such as compensation, roles in campus governance, access to resources and support services, and, most importantly, the level of budgetary support allocated to libraries by campus administration." 43

The lack of understanding about the academic librarian's professional role and responsibilities can be disempowering to library faculty in a number of ways. According to Ken Kempcke, it is often difficult for librarians to "[mobilize] themselves to operate effectively in the collegiate political arena." ${ }^{\prime 4}$ Often, communicating the needs and contributions of the academic library to unit heads and university-level administrators is frequently left to the library dean or director. As the concerns and priorities of higher education institutions shift and change, it is imperative that all academic librarians be given a voice and recognition that they, too, are partners in the academic enterprise.

\section{Academic Librarians' Education and the Terminal Degree}

An important component of the Human Resource frame is employee-organizational "fit," which is frequently gauged by considering the employee's qualifications in respect to the demands of the position. One of the more significant differences between academic librarians and disciplinary faculty is the terminal degree typically required for each position. While there are notable exceptions for each type 
of position, the ALA-accredited master's is usually the requirement for academic library positions, while disciplinary faculty are most frequently expected to hold the doctoral degree. ${ }^{45}$ Over the years, there has been significant discussion in the library literature regarding the extent to which librarians' qualifications fit the profile of "faculty member," specifically the adequacy of the ALA-accredited master's as the academic librarian's sole and terminal degree.

In 1975, the Association of College and Research Libraries (ACRL) approved as policy its Statement on the Terminal Professional Degree for Academic Librarians, which affirmed the ALA-accredited master's degree as the appropriate terminal degree for academic librarians. ${ }^{46}$ While the ACRL maintains this position, and even reaffirmed the Statement as recently as 2011, a number of individuals have called it into question. Phillip Jones reviewed the robust discussion of credentials for academic librarians that appeared in the professional literature prior to ACRL's issuing its first Statement, which he assessed as being largely supportive of academic librarians, having additional graduate degrees. According to Jones, the Statement had a "chilling effect" on further deliberation; far fewer essays discussing the topic were published in the LIS literature in the 23 years between the Statement's issue and Jones' essay. ${ }^{47}$

A number of arguments express favor for academic librarians' earning additional graduate degrees, but much of the literature centers on a few specific benefits of doing so. Chief among these seems to be the increased opportunity for academic librarians to acculturate to academic life, improve their subject knowledge, and enhance their reputation and visibility among other faculty members. Authors also mention the not-insignificant issue of career development, citing the policy maintained by some institutions prohibiting a faculty member's promotion to full professor without an earned doctoral degree. $^{48}$
In addition to discussing the ways in which an advanced degree can improve an academic librarian's ability to interact with the relevant discipline's faculty and collections, studies related to the desirability of academic librarians, earning additional graduate degrees often discuss their preparedness for conducting original research. Doctorate-holding academic librarians who responded to Todd Gilman and Thea Lindquist's survey cited "in-depth understanding of the research process" as one of the main advantages of having earned a subject doctorate. One respondent in a tenure-track position specifically credited the experience of writing a dissertation and revising it for publication as a monograph for significantly reducing his anxiety about the research requirements of a library faculty position. ${ }^{49}$ Jennifer Mayer and Lori Terrill reported that many of the academic librarians with advanced subject degrees who responded to their survey on the topic identified "development of research skills" as one of the most important benefits of earning a graduate degree beyond the ALA-accredited master's. ${ }^{50}$

On the other hand, when the respondent pool is broadened to include academic librarians without subject doctorates, there is evidence that many academic librarians feel neither sufficiently prepared for nor enthusiastic about designing and conducting original research. This is unsurprising, given that in 2010 only 61 percent of U.S. ALAaccredited master's programs required students to complete a research methods course. $^{51}$ New academic librarians who participated in Laura Sare, Stephen Bales, and Bruce Neville's mixed-method study described the process of conducting original research as "unsatisfying or confusing." ${ }^{52}$ Respondents to Johnson and Lindsay's survey who indicated that they were in a faculty-status position (half of the total participants) identified publishing as the aspect of the job they found most challenging and for which they were least prepared. ${ }^{53}$ Additionally, re- 
spondents felt that publishing was among the least personally satisfying aspects of their work, and the area of responsibility with the smallest impact on services to users. ${ }^{54}$ These findings led the authors to recommend that master's programs and academic libraries need to increase their emphasis on orienting students and new academic librarians to the intricacies of academic publishing. ${ }^{55}$

While discussion regarding how well librarians "fit" into the academy is likely to continue, less attention is given to the needs of librarians and ways in which the institution might adjust to address those needs. Marie Kennedy and Kristine Brancolini's survey about academic librarians' engagement with research included questions about their institution's support of research activities. While 56 percent and 57 percent of respondents reported that travel funds and research skills-related workshops, respectively, were made available by their employers, 12 percent of respondents said that no support was provided to them whatsoever. The authors also pointed out that, while "the most critical aspect for conducting research is time," 61 percent of respondents' employers did not afford release time for conducting research and writing. ${ }^{56}$ This imbalance directly reflects the absence of a shared philosophy about the role of library faculty across the academy and deserves further attention.

\section{Political Frame}

Unlike the Structural and Human Resource frames, the Political frame depicts institutions as the sum total of interactions among the people in the institution rather than the composites of rules, guidelines, initiatives, and philosophies constructed by organizations. According to the Political frame, the scarcity of resources such as physical space, prestige, recognition, personnel, and discretionary funds are treated as drivers of personal interactions. Since institutions have finite resources, actors build networks and form coalitions to secure those resources and to navigate the inevitable conflict. However, diversity among staff (as defined by differences in education, experience, salary, social status, and other factors) exacerbates the conflict over resources and challenges coalition building, as interest in resources become entangled with or expressed as other interests. The Political frame attributes problems within the organization to human failures to "map" the political terrain, a process that includes understanding others' interests and how they might act to protect those interests. ${ }^{57}$ Actors who ignore the political terrain place their own interests in jeopardy and may create conditions that provoke reprisals. Also, people may misread the political terrain if they use it to understand the formal leadership only. While the Structural frame assumes that control and power within an organization follow an explicit and established pattern of responsibilities, the Political frame suggests that leadership can flow from many informally defined directions.

The Political frame contributes to a number of insights about the relationships between library faculty and the academy. All too frequently, the literature presents the relationship between the academic librarian and his or her constituents as adversarial rather than collegial. In 1995, Larry Hardesty complained that disciplinary faculty can be particularly troublesome when library materials are involved because they are only interested in their own research and are unconcerned about the library's cultivating a collection that is also useful to the undergraduate students of the institution. ${ }^{58}$ In his 1999 study of disciplinary faculty -librarian relations, Wade Kotter related a finding from the survey literature regarding disciplinary faculty perceptions of librarians: they "often rate librarians as one of the least likely sources to which they would turn when seeking information." ${ }^{59}$ According to José A. Montelongo, Lynne Gamble, Navjit Brar, and Anita C. Hernandez, disciplinary faculty consider themselves to be "producers 
and disseminators of knowledge," while they view librarians as service providers. ${ }^{60}$ Kempcke considers this unfortunate because academic librarians could contribute significantly to disciplinary faculty research: "often, the librarian's knowledge of the tools and processes required for inquiry constitutes a certain advantage over other faculty." ${ }^{61}$ Pauline Wilson referred to this arrangement while discussing academic librarians' teaching role, saying that, rather than considering academic libraries to be an integrated parts of the overall academic system and process, disciplinary faculty see academic libraries as "somehow separate education agencies, operating more or less independently in some vague, undefined way." ${ }^{62}$

\section{Faculty Status for Librarians: The Disciplinary Faculty's View}

Between 50 and 60 percent of U.S. institutions of higher education offer faculty status to their librarians. ${ }^{63}$ However, a review of the literature indicates that this official recognition has not necessarily translated into disciplinary faculty members' seeing librarians with faculty status as peers. Writing in 1942, literature professor N.P. Barksdale attributed this attitude to disciplinary faculty members' "conviction that librarians are merely technicians, trained in certain mechanical details but lacking a rich cultural background which would entitle them to equal professional recognition with faculty members," adding that "in the main, this conviction is well founded." ${ }^{64}$ More recently, G.W. Thompson, an English professor at Earlham College, offered this in a series of explanations for the recalcitrance of some disciplinary faculty to collaborate with librarians: "[faculty] regard librarians as they regard secretaries and ground keepers, as their errand boys and girls, not as their colleagues." ${ }^{65}$

Academic librarians, hoping that faculty of Library and Information Science programs might support their quest for faculty status, have largely been disappointed. In a scorching 1979 essay, Wilson denied any "basis for recognition [of librarians as peers]" because "there is nothing visible with which a connection can be made to permit or produce recognition ... between the librarian and his or her occupational role and the faculty member's." ${ }^{\prime 6}$ In a Library Journal essay expressing disapproval of faculty status for librarians in more personal terms, Blaise Cronin, then Dean of Indiana University's School of Library and Information Science, said that hearing the "dreaded words library faculty status" caused him to "cringe." "67 In the first empirical study of LIS faculty attitudes about the appropriateness of faculty status for academic librarians, Wyss invited the 906 tenure-line faculty of the 57 LIS programs accredited by the American Library Association to complete a survey, 187 of whom did so. Participants in the study responded favorably to academic librarians with faculty status being eligible for participation in campuswide faculty governance and agreed that their doing so could have a positive effect on disciplinary faculty members' perception of academic librarians. They also agreed that faculty-status academic librarians should have the opportunity to take research leave. However, they were undecided on the questions of the fundamental appropriateness of academic librarians having faculty status; whether facultystatus librarians should be compensated at the same level as faculty colleagues from other areas; and whether faculty librarians should be subject to the same publication standards, evaluation criteria, and tenure policies as disciplinary faculty members. ${ }^{68}$

While the LIS literature presents an abundance of research related to librarian-disciplinary faculty relations, the topic has received very little coverage in the scholarship of other disciplines. Christiansen et al. call this relationship an "asymmetrical disconnection." ${ }^{69}$ The authors conducted a series of interviews and focus groups with librarians and disciplinary faculty members to determine each group's perception of the librarian/ 
disciplinary faculty relationship. They found that, while both librarians and disciplinary faculty perceived a lack of connection between the two groups, only the librarians viewed this as a problem. Furthermore, while the librarians who participated in the study were able to describe the work of disciplinary faculty accurately and felt a strong responsibility to assist them in their endeavors, the disciplinary faculty participants considered the librarian's essential role to be collecting sources and providing access to the collection, not supporting disciplinary faculty members' research and teaching efforts. In fact, the disciplinary faculty had little understanding of the work of academic librarianship beyond collection development and reference work. Findings from the series of faculty surveys conducted by ITHAKA S + R support this assertion; comparing findings from the 2003, 2006, and 2009 surveys reveals that faculty have become progressively less likely to begin a research project in the library or by consulting with a librarian. ${ }^{70}$

According to Markus Lücken and Bernd Simon, the asymmetrical disconnection" espoused by Christiansen et al. "represents a common dynamic for members of a minority group within a larger group. In their study of numeric minority-majority group relations in four different experimental settings, the authors found that members of the smaller groups experienced "heightened awareness of their group membership and affective strain." ${ }^{\prime 71}$ Lücken and Simon attributed this experience to the members of the smaller groups' perceiving themselves as being "particularly vulnerable to a (further) power disadvantage." ${ }^{\text {72 }}$ Lücken and Simon add that this awareness does not extend to members of the majority group, as "minority group members are cognitively preoccupied with their group membership more than majority members."73

It is important to recognize that, although the study participants internalized their status, their internalization was preceded by an empirical state of disadvantage. Even when majority-minority status is defined along racial axes, the advantage enjoyed by members of the majority group allows them to remain oblivious of the disparities between the two groups. ${ }^{74}$

Although librarians have gained some ground in their attempts to convince disciplinary faculty to allow them to share their class time and provide librarians access to students to discuss literature supported research strategies and techniques, this acceptance has been slow in coming. ${ }^{75}$ Why have librarians had so little success? There are several reasons cited in the literature, and most boil down to a disconnect between librarians' and disciplinary faculty members' feelings about the importance of teaching. Academic librarians' discussion of "teaching" faculty ${ }^{76}$ misses an important point: at many universities, teaching is not the primary occupation of disciplinary faculty members. As Donald Riggs points out, research productivity is the "number one criterion" considered in tenure and promotion decisions for many faculty members, especially at research universities. ${ }^{77}$ As this is less likely to be the case for an academic librarian with faculty status, regardless of institution type, ${ }^{78}$ many academic librarians may not have fully internalized the pressure on disciplinary faculty to research and publish, sometimes to the detriment of their teaching responsibilities. ${ }^{79}$ On the other hand, some have suggested that the emphasis disciplinary faculty place on maintaining control of their courses may make them reluctant to allow "librarians to encroach into faculty held territory," even for a brief period. ${ }^{80}$

Analysis using the Political frame shows that the dynamics discussed in this section are the natural outgrowths of institutional life. Therefore, the responsibility for these dynamics also rest with administrators who can increase librarians' capacity through the provision of marketable services, such as repositories. By providing venues that can showcase 
librarians'capacity to support faculty research, institutional repositories could garner positive attention for librarians. However, libraries have given limited and inconsistent attention to institutional repositories, which have often been the first casualties of budget cuts. Also, where libraries have attempted to pool resources through repository consortia, representatives to the consortia have typically been staff with little decision-making authority within their own libraries. ${ }^{81}$

This frame also supports the notion that "where you sit is where you stand," as both library and disciplinary faculty take positions that maximize their resources such as time, prestige, and compensation. In addition, considering an issue through the Political frame demonstrates that active management of tensions and public perception, as opposed to avoiding tensions altogether and allowing them to continue along their historical trajectories, would be better uses of resources. As a final note here, it may be the case that university and library administrators' political finesse has allowed them to remain above the fray and allowed the tensions between library and disciplinary faculty to receive the lion's share of attention in this ongoing conversation.

\section{Symbolic Frame}

Bolman and Deal's Structural, Human Resource, and Political frames (to a lesser extent) all concern factors that can be taken at face value. Actors can identify standard operating procedures, they can refer to a written human resource philosophy, and they can point to the formal resource allocations, even if they do not fully recognize coalitions vying for those resources. The Symbolic frame, as its name suggests, is more elusive because it dwells in the realm of the implicit. What meaning do we attach to policies and procedures? What does the discrepancy in resource allocation among units say about their nonmonetary value in the larger institution? In the Symbolic frame, what actors perceive ... is.
While institutions are composed of structures, people, and the interactions among them, institutions also live in the stories and tales about the institution. These stories help "spark action, communicate who someone is, communicate who the company is - branding, transmit values, foster collaboration, tame the grapevine, share knowledge, and lead people into the future." ${ }^{\prime 2}$ The stories need not be true or based in reality, only effective. Stories have heroes and heroines who provide "comfort, reassurance, and hope." 83 They also explain why people should "revere the institution." ${ }^{84}$ For example, there are powerful narratives about the transformative nature of higher education reinforced by its connection to the United States' Manifest Destiny. In addition, stories are replete with metaphors, which act as shorthand or icons for a range of thoughts, feelings, and affections. Anna McEwan comments that a teacher who describes his role as that of an artist, coach, or tour guide is indicating intent to relate to students in three clearly distinguishable ways. ${ }^{85}$

Two studies are identified here that focus on campus administrators' views regarding the symbolic power of the academic library, especially in connection with establishing priorities for resource allocation. Specifically, researchers have asked college and university provosts and presidents if the metaphor of the library as the "heart" of the university held resonance for them. Deborah J. Grimes interviewed chief executive and academic officers at seven universities for the first study, conducted in the early 1990s. ${ }^{86}$ She found that, while the statement still held meaning for the administrators she interviewed, the symbolic significance of the library seemed to be shifting from being a storehouse of knowledge to that of a "crossroads community" of centrally located facilities to support the work of the university, especially learning. Beverly P. Lynch, Catherine Murray-Rust, Susan E. Parker, Deborah Turner, Diane Parr Walker, Frances C. Wilkinson, and Julia 
Zimmerman replicated Grimes' study in 2004. The authors were particularly interested in determining if the dramatic developments in information technology had influenced administrators' perception of the symbolic significance of the library. While most of the respondents acknowledged that the remote access capabilities had reduced the need for faculty and students to visit the brick-and-mortar building, the library remained "the place where the symbolic and practical depiction is made of what the university does academically." ${ }^{87}$ While both studies focused on the library rather than the role of librarians, Lynch et al. make the following point regarding librarians' contribution to the continued centrality of the library to the higher education mission:

Libraries have positioned themselves as a critical component of the teaching, research, and service mission of the university and have expended much effort to convince key campus players of this. ${ }^{88}$

\section{Academic Librarians and the Faculty Image}

Several of the factors described as having significance from a human resources perspective, such as librarians' educational requirements and employment status, have symbolic power as well. This is most evident in the historic tension between academic librarians' self-perception and disciplinary faculty members' attitudes about appropriate roles for academic librarians. For example, William Goode commented that the public views the librarian as a "gatekeeper and custodian of the stock-room. ${ }^{\prime \prime 9}$ Fundamentally, their constituents frequently misunderstand librarians' role and responsibilities in the academic setting. In an analysis of the professional roles of academic librarians, LIS faculty member Wilson wondered "what is there about the work of librarians that could cause them to be a target for popular aggression?" positing that "it may be the fact that the librarian is always in the uncomfortable position of having to portion out scarce resources" through control of the purchasing budget, imposition of rules and restrictions, and, when patrons fail to follow the rules, "the librarian will impose sanctions, such as fines." Wilson went on to issue a warning to librarian readers: "a pleasant personality and a friendly smile will not serve to shield the librarian from the ill will generated by these inescapable features of a librarian's work." $" 90$

As already noted, there is usually a discrepancy between the educational levels of librarians and disciplinary faculty at any given institution. The librarians who began working in academic libraries in the early 1900 s were usually young women who had completed a sort of post-bachelor's trade course, while the MLS degree itself was not a widespread requirement until the 1940s. Currently, it is relatively uncommon for rank-and-file academic librarians-even those with faculty status and tenure requirementsto hold the doctoral degree..$^{91}$ Those in administrative positions in academic libraries are more likely, although not required, to have earned a doctorate (in LIS or another field) than rank-and-file academic librarians are. ${ }^{92}$

Some consider the lack of a doctoral degree to be a fundamental impediment to full integration into the academy, which prizes knowledge development above most other goals. In 1999, librarians W. Bede Mitchell and Bruce Morton opined that, because most librarians had not completed a doctoral program, they were not only unprepared to conduct their own research but also "lack[ed] an empathetic appreciation of the rigors and methodology of research. ${ }^{\prime \prime 3}$ Mitchell and Morton considered what they believed to be academic librarians' inexperience with the process of conducting original research a major contributing factor to their status in the academy.

There is evidence that librarians who adopt the symbolic trappings of the faculty scholar are more likely to be seen as 
peers by disciplinary faculty. To explore the qualities and qualifications that might contribute to librarians' being considered colleagues by disciplinary faculty, Major interviewed eighteen academic librarians identified by their libraries' deans and directors as having achieved this status. Most of the respondents were active participants in campus committees and faculty governance, and several had their own active research agendas and/or participated in research-related activities outside the library. Some respondents who had earned doctoral degrees identified having done so as a major factor contributing to their status and visibility. ${ }^{94}$ While Mitchell and Morton may have phrased their comments less than charitably, their message may contain some important truths about the symbolic value of librarians' participation (or lack thereof) in research. Because producing original scholarship is one of the most powerful symbols of academic participation, several authors have observed that librarians' commitment to this endeavor sends a powerful message to disciplinary faculty. ${ }^{95}$ This could also affect the view of outside stakeholders. Christiansen et al. highlighted the disproportionate value that society typically places on knowledge production (disciplinary scholarship) as opposed to service (librarianship). ${ }^{96}$

The symbolic role of librarians in society and in the academy has been quite powerful and has constrained library faculty in a number of ways. However, this symbolic role is related to some degree to factors that have nothing to do with qualifications or output. For example, sociologists Christiansen et al. suggested that librarianship was still considered "women's work," which has typically been undervalued. ${ }^{97}$ The impact of this factor cannot be underestimated in considering the differences in librarian and disciplinary faculty status. It is worth noting that, while women still largely dominate the profession of librarianship overall, men are disproportionately wellrepresented in leadership positions in academic libraries, ${ }^{98}$ as is typical throughout the academy ${ }^{99}$ However, because the profession of librarianship is considered gendered, male librarians are painted with the same brush as female practitioners. This was the case in 1979, when Wilson asserted that "the stereotype is more than that popular image, and it includes both sexes. Some of the elements that have been identified in it are passivity, submissiveness, conformity, conservatism, introspection, lack of self-confidence, lack of sociability, and bookishness." ${ }^{100}$ Negative perceptions have not eased with time; a variety of more recent studies identified "low prestige" as a quality frequently ascribed to the profession of librarianship, even by students enrolled in a master's program. ${ }^{101}$ According to Maura Seale's analysis of mass media, librarians are frequently (and unfairly) depicted as "old maids, policemen, and social rejects."102

Unfortunately, a hallmark of the academic library subculture seems to be a perpetual struggle with self-image. This outlook is evident in the library literature, according to Kempcke, which "supports a representation of librarians as handmaidens, secondary in importance to more scholarly and proficient 'disciplinary faculty.'"103 In his 1997 essay encouraging librarians to embrace the role of "librarian-scholar," then-Assistant Director for Research Resources at Harvard University Library Kenneth Carpenter theorized that librarians' poor self-image stems in part from ambivalence about membership in the profession itself. Carpenter contended that university librarians often "start out to be faculty and then for one reason or another become librarians." As a result, he says, "they tend-by no means is it universal-not to be proud of being librarians, especially since librarians do not stand high in the social ranking of the academic world." ${ }^{104}$ Remarkably, Carpenter offers no empirical evidence in support of his statement, instead citing a source also based in opinion. Presumably, at the same time that she was teaching students who would eventually become 
librarians, LIS faculty member Wilson characterized librarians as having "an inordinate passion for status." Having come to the realization that their professional status is low, Wilson said that librarians "sought relief from the stereotype by seeking to use the occupational title of a different profession," teacher, in hopes of "buttress[ing] a claim to a higher status or a claim to more prestige." ${ }^{105}$ Walter ascribes less nefarious motivations to librarians who seek recognition of their instructional role, saying that they merely "want to be recognized as part of an intellectual profession but feel that public perception relegates them more often to the role of clerks." ${ }^{106}$ It is important to bear in mind that all of these assessments, regardless of tone, largely represent normative, not empirical, understandings of these dynamics.

The library literature demonstrates empirically that academic librarians with faculty status are not compensated on a level equal to disciplinary faculty of the same rank. ${ }^{107}$ The implication of this incongruity is that the work of academic librarians is less valuable or important than that of the institutions' other assistant, associate, and full professors. While remuneration has previously been discussed in the literature in terms of its significance to the Structural and Human Resource frames, one's salary holds symbolic significance as well. Regardless of the roles and responsibilities library faculty assume in institutions, the ways these roles and responsibilities are perceived by the academy and the ways in which librarians perceive these roles themselves can be even more powerful than verifiable "facts." In their study of minority/majority group relations, Lücken and Simon attributed the minority group members' anxiety and negative effect to their perception of their own powerlessness, not a lack of status. The authors differentiate the former as a concept that the authors specify "revolves around doing which includes (the capacity for) doing, or making others do, something to one's own advantage and/or to other people's disadvantage," while the latter involves "being or, more precisely... being esteemed and (considered) good or even superior" (emphasis in original). ${ }^{108}$ This distinction presents an interesting perspective on the issues surrounding academic librarians' status and self-image and may be worthy of further exploration.

\section{Looking to the Frames for Guidance}

While Bolman and Deal's four frames provide perspective for library and disciplinary faculty and university and library administrators as they consider issues associated with librarians' position in the academy, the frames also provide perspective on actions to be taken in response to these issues. Because structural and human resource-related remedies are largely outside academic librarians' realm of influence, it seems most prudent for librarians to focus their negotiations for status on human resource (to a lesser extent), political, and symbolic factors, such as the acquisition of doctoral degrees, management of tensions, and support for acquisition of institutional repositories.

Kempcke feels that administrators' and outside stakeholders' increasing emphasis on quality teaching, active learning approaches, and curricular reform may be the librarian's ticket to integrating into the larger community. ${ }^{109}$ Identifying allies within the disciplinary faculty is another recommended approach; in a study done at Albion College, Visual Arts faculty were most accepting of librarians as equals, while a more recent study conducted at the University of Manitoba revealed that librarians were least valued by the faculty in the applied sciences and valued most highly by the education faculty. ${ }^{110}$ This may be related to the fact that education faculty have led the charge to mainstream the scholarship of teaching into the academic culture. Perhaps as the movement grows in prominence, disciplinary faculty will be more open to the benefits available to their students through collaboration with librarians. Library administrators can support these efforts by communicat- 
ing with their peers from across campus about the services and resources available to disciplinary faculty, staff, and students in the library, and by providing librarians with the resources they need to support instructional efforts.

Opportunities for library and disciplinary faculty collaboration are often overlooked, and, unfortunately, disciplinary faculty may not be fully aware of the assistance that librarians can provide. Kina S. Mallard's article, "The Soul of Scholarship," explores the phases of an academic's career. She states that new disciplinary faculty members often feel frustrated and do not know how to proceed with their research beyond the "idea file" stage. Although Mallard suggests that it is the job of "colleagues, department chairs, and faculty development centers" to help the professor move forward in her or his research, the academic librarian is notably absent among members of this support team. ${ }^{111}$ Although some academic librarians might possess limited knowledge of the content of a disciplinary faculty member's research interests, assembling materials and sources is one of the main weapons in the librarian's arsenal. Julie Arendt and Megan Lotts conclude that disciplinary faculty who were in frequent and personal contact with their librarian liaison were most likely to report that they were "satisfied" or "very satisfied" with the liaison's performance. ${ }^{112}$ Successful connections between library and disciplinary faculty create opportunities for long-term collaborations. As new disciplinary faculty mature as researchers and earn tenure, they will see the value added by their relationship with librarians in general and librarians with faculty status in particular.

Librarians might want to make more deliberate efforts to absorb the values of scholarship. To be taken seriously by disciplinary faculty, says Kempcke, "it is vitally important that librarians measure up to the publishing standards of their campus colleagues - that they participate in the production of scholarly research, which is a critical component of good teaching and camaraderie in the academy." 113 Reaching out to faculty in the arena of scholarly research is a good idea as well. Hardesty advises librarians to increase their publication efforts in journals outside the LIS discipline. Montelongo et al. second this call, saying that, by pursuing a robust research agenda outside LIS, "college librarians can elevate their personal status among their non-library colleagues and students, as well as the prestige of their library and the library profession." ${ }^{114}$ As the literature points out, many academic librarians arrive on campus without the knowledge or skills they need to hit the ground running with a research agenda. ${ }^{15}$ To bolster these efforts, library administrators must be proactive in both providing new employees with opportunities to enhance their knowledge of research design and methods and in creating and promoting an institutional framework to support new researchers. Also, it is essential that library administrators support their scholar-librarians by providing financial resources for costs associated with research projects such as publicity and participant incentives, as well as the time to conduct, write, and present research.

The library is referred to by some in academe as "the bottomless pit (of money)." ${ }^{\prime 16}$ As a counter-narrative, the new emphasis on increasing enrollment and tuition dollars through distance education $^{117}$ may contribute to the recognition of the librarian's values and skills. Librarians have stepped up to provide assistance to distance-education students through chat service, tutorials, individualized instruction, specially designed web resources, and more. Librarians are also beginning to focus their collaborative efforts successfully at campus programs such as Student Affairs and Athletics.

Finally, the current emphasis on developing methods and tools for demonstrating academic libraries and librarians' value to and impact on the mission of the larger institution of higher education is 
encouraging. While significant progress has been made in demonstrating the utility of library collections for supporting faculty research, funded and otherwise, fewer studies have explored the impact of library services such as instruction and reference. ${ }^{118}$ Several projects of this type are currently in progress, however, and may provide academic libraries with useful models that can be adapted for use at their own institutions. ${ }^{119}$

By addressing the areas over which they have most control-specifically, the political and symbolic aspects of their roles in the academy-librarians are most likely to increase their esteem in the eyes of disciplinary faculty. As a result, librarians may be able to effect change also in the structural and human-resource spheres. In showing the value they add to the academic enterprise, librarians also demonstrate the important support they provide to the overall institutional structure. Given the financial constraints academic institutions face, as we all heed the clarion calls for advancements in the face of austerity, librarians must help decision makers and other stakeholders understand that these advancements are impossible without librarians' expertise.

The following table summarizes the issues outlined in this paper and recommends actions to help remedy the situation. These suggestions are largely untested, but they would be interesting areas for future exploration. The responsibility for clarifying the librarian's place in the academy rests not with the librarian alone but should be shared by library and upper-level library administration, as well as university administration and disciplinary faculty, whenever possible. 


\begin{tabular}{|c|c|c|c|c|}
\hline \multicolumn{5}{|c|}{$\begin{array}{c}\text { TABLE } 1 \\
\text { Librarians' Role in the Academy: Issues and Suggested Remedies, by Frame }\end{array}$} \\
\hline Frame & $\begin{array}{l}\text { Locus of } \\
\text { Responsibility }\end{array}$ & Frame-Related Issues & Change Agents & Actions Suggested by the Frame \\
\hline \multirow[t]{3}{*}{$\begin{array}{l}\text { Structural } \\
\text { (institutional } \\
\text { factors) }\end{array}$} & \multirow[t]{3}{*}{ Institution } & $\begin{array}{l}\text { Integration of librarians' roles } \\
\text { in distance education classes }\end{array}$ & \multirow[t]{3}{*}{ Library Administrators } & $\begin{array}{l}\text { Build a multiyear metric into library's strategic plan that } \\
\text { measures progress on extending these services to departments } \\
\text { Treat DE support/teaching as a primary function of the library } \\
\text { organization } \\
\text { Institute campaign to publicize librarians' contributions to } \\
\text { successful DE efforts (also Symbolic) }\end{array}$ \\
\hline & & $\begin{array}{l}\text { Disparate tenure requirements } \\
\text { between library and } \\
\text { disciplinary faculty } \\
\text { Disparate experiences and } \\
\text { educational qualifications } \\
\text { required for library and } \\
\text { disciplinary faculty }\end{array}$ & & $\begin{array}{l}\text { Enact policies that reward increase in research skills, output, } \\
\text { and visibility, especially in disciplines outside LIS; Further } \\
\text { graduate education (also HR) } \\
\text { Enact reward system that includes positions requiring doctoral } \\
\text { degree; Devise system so that administrators can directly } \\
\text { compare library faculty research, teaching, and service to } \\
\text { academic faculty (also HR) } \\
\text { Initiate pay equalization study across campus (also requires } \\
\text { actions from Institutional Administration) }\end{array}$ \\
\hline & & $\begin{array}{l}\text { Physical separation of library } \\
\text { faculty from disciplinary } \\
\text { faculty }\end{array}$ & & $\begin{array}{l}\text { Build multiyear initiative into strategic plan to "embed" } \\
\text { librarians in academic departments } \\
\text { Build multiyear initiative into strategic plan for librarians } \\
\text { to participate in campus committees, governance, other } \\
\text { opportunities and programs to increase visibility and access } \\
\text { Repurpose spaces within academic departments that others } \\
\text { consider unusable; Use for librarian office hours }\end{array}$ \\
\hline
\end{tabular}




\begin{tabular}{|c|c|c|c|c|}
\hline \multicolumn{5}{|c|}{$\begin{array}{c}\text { TABLE } 1 \\
\text { Librarians' Role in the Academy: Issues and Suggested Remedies, by Frame }\end{array}$} \\
\hline Frame & \begin{tabular}{|l|} 
Locus of \\
Responsibility
\end{tabular} & Frame-Related Issues & Change Agents & Actions Suggested by the Frame \\
\hline \multirow[t]{4}{*}{$\begin{array}{l}\text { Structural } \\
\text { (institutional } \\
\text { factors) }\end{array}$} & \multirow[t]{4}{*}{ Institution } & $\begin{array}{l}\text { Library faculty work } \\
\text { structured by library } \\
\text { administrators; disciplinary } \\
\text { faculty work self-directed }\end{array}$ & Library Administrators & $\begin{array}{l}\text { Increase librarians' scheduling flexibility (on daily, weekly, } \\
\text { monthly, and/or annual basis/es) (also HR) } \\
\text { Promote team-based rather than hierarchical style collaborations } \\
\text { within the library organization (also HR) }\end{array}$ \\
\hline & & $\begin{array}{l}\text { Nonfaculty librarians-- } \\
\text { no or limited governance } \\
\text { responsibilities; } \\
\text { Disciplinary faculty- } \\
\text { governance responsibilities }\end{array}$ & $\begin{array}{l}\text { Institution } \\
\text { Administrators }\end{array}$ & $\begin{array}{l}\text { Seek out librarians for participation in governance and to } \\
\text { represent the university in broader communities; } \underline{\text { Include }} \\
\text { librarians in lecture series and other intellectual exchanges on } \\
\text { campus }\end{array}$ \\
\hline & & $\begin{array}{l}\text { Nonfaculty librarians-no } \\
\text { or limited governance } \\
\text { responsibilities; } \\
\text { Disciplinary faculty- } \\
\text { governance responsibilities }\end{array}$ & Library Administrators & $\begin{array}{l}\text { Allow time for library faculty to pursue and participate in } \\
\text { governance opportunities on campus and with local, state, } \\
\text { national, international infrastructure projects and other decision- } \\
\text { making processes; Publicize these efforts (also Symbolic); } \\
\text { Build multiyear initiative into strategic plan for librarians } \\
\text { to participate in campus committees, governance, other } \\
\text { opportunities and programs to increase visibility and access } \\
\text { (also HR) }\end{array}$ \\
\hline & & $\begin{array}{l}\text { Redefinition of university } \\
\text { missions }\end{array}$ & $\begin{array}{l}\text { Institution/Library } \\
\text { Administrators }\end{array}$ & $\begin{array}{l}\text { Assess in a systematic way the value that local and virtual } \\
\text { services bring to the institution }\end{array}$ \\
\hline
\end{tabular}




\begin{tabular}{|c|c|c|c|c|}
\hline \multicolumn{5}{|c|}{$\begin{array}{c}\text { TABLE } 1 \\
\text { Librarians' Role in the Academy: Issues and Suggested Remedies, by Frame }\end{array}$} \\
\hline Frame & $\begin{array}{l}\text { Locus of } \\
\text { Responsibility }\end{array}$ & Frame-Related Issues & Change Agents & Actions Suggested by the Frame \\
\hline \multirow[t]{3}{*}{$\begin{array}{l}\text { Human } \\
\text { Resource } \\
\text { (institutional } \\
\text { and human } \\
\text { factors) }\end{array}$} & \multirow[t]{2}{*}{ Institution } & $\begin{array}{l}\text { No philosophy shared } \\
\text { across institutions about } \\
\text { roles of library faculty- } \\
\text { disempowering; philosophy of } \\
\text { disciplinary faculty defined by } \\
\text { status of institution (Research } \\
\text { I, II, Liberal Arts) }\end{array}$ & \multirow[t]{2}{*}{ Library Administrators } & $\begin{array}{l}\text { Capitalize on ACRL/AAUP joint study of librarian faculty } \\
\text { status } \\
\text { Recognize librarian/library faculty contributions in a way that } \\
\text { extends beyond the library } \\
\text { Facilitate librarians' professional and scholarly development } \\
\text { Support participation in non-LIS-related conferences } \\
\text { Work closely with the research office to coordinate research } \\
\text { efforts and to quantify research contributions from library } \\
\text { faculty }\end{array}$ \\
\hline & & \multirow[t]{2}{*}{ Increase in DE services } & & $\begin{array}{l}\text { Increase internal assessment efforts to establish, document, } \\
\text { and publicize the value librarians/faculty add by being heavily } \\
\text { involved in DE and other new services (also Structural) } \\
\text { Reward creativity related in suggesting or designing new } \\
\text { services }\end{array}$ \\
\hline & $\begin{array}{l}\text { Library } \\
\text { Faculty }\end{array}$ & & Librarians & $\begin{array}{l}\text { Seek grants to enhance the provision of DE services } \\
\text { Deliver webinars and other training modules on best practices } \\
\text { Develop full-course modules to share with academic faculty }\end{array}$ \\
\hline $\begin{array}{l}\text { Political } \\
\text { (human } \\
\text { factors) }\end{array}$ & $\begin{array}{l}\text { Library } \\
\text { Faculty }\end{array}$ & $\begin{array}{l}\text { Struggle to find allies through } \\
\text { teaching, conducting research, } \\
\text { supporting others' research }\end{array}$ & Librarians & $\begin{array}{l}\text { Identify allies: } \\
\text { New academic faculty } \\
\text { Academic faculty from "sympathetic" disciplines (education, } \\
\text { LIS) } \\
\text { Graduate students-long-term acculturation }\end{array}$ \\
\hline
\end{tabular}




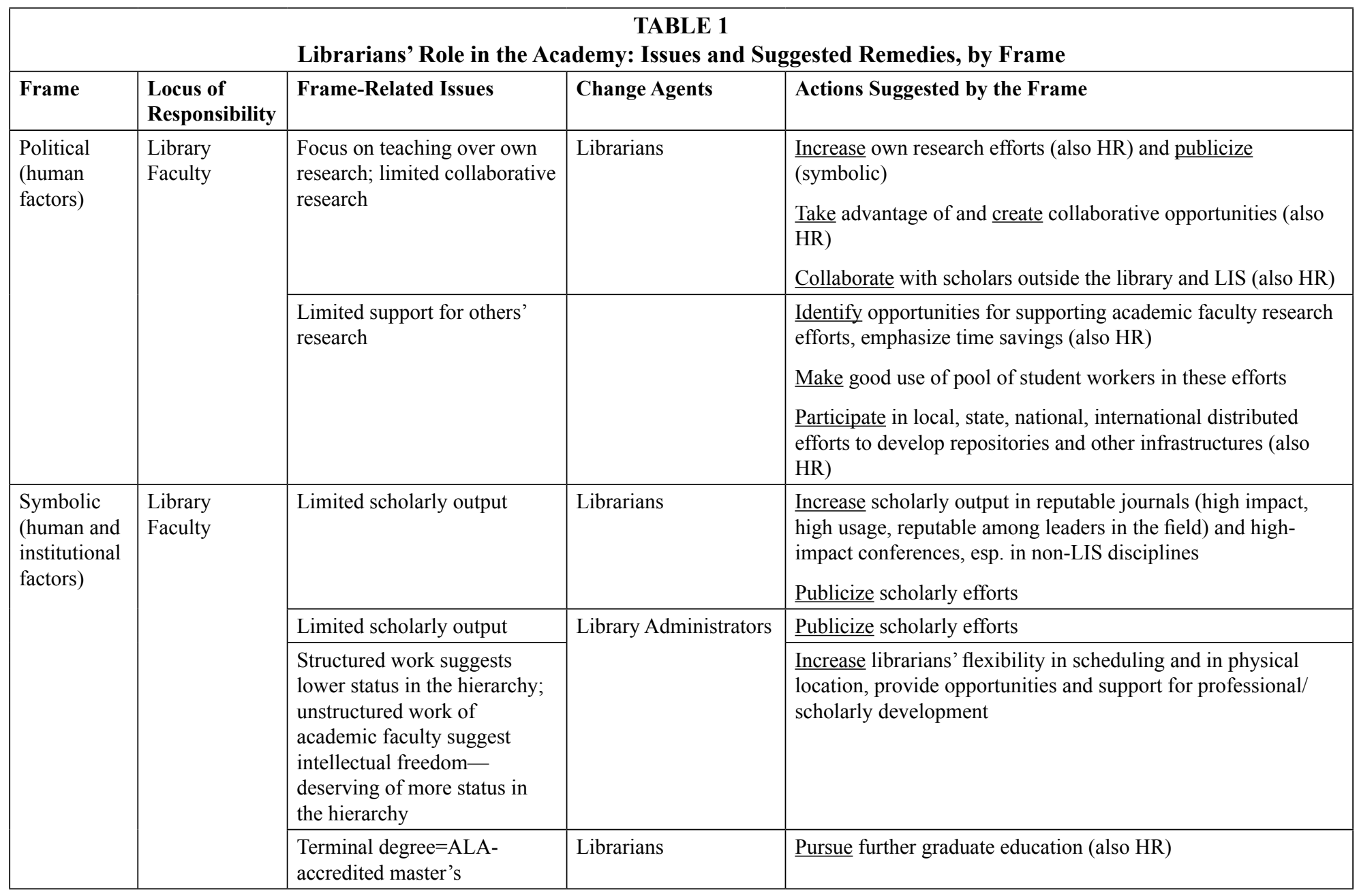




\begin{tabular}{|c|c|c|c|c|}
\hline \multicolumn{5}{|c|}{$\begin{array}{c}\text { TABLE } 1 \\
\text { Librarians' Role in the Academy: Issues and Suggested Remedies, by Frame }\end{array}$} \\
\hline Frame & \begin{tabular}{l|} 
Locus of \\
Responsibility
\end{tabular} & Frame-Related Issues & Change Agents & Actions Suggested by the Frame \\
\hline $\begin{array}{l}\text { Symbolic } \\
\text { (human and } \\
\text { institutional } \\
\text { factors) }\end{array}$ & Institution & $\begin{array}{l}\text { Less value-people do not } \\
\text { care enough to understand the } \\
\text { different roles and } \\
\text { responsibilities of library } \\
\text { staff; roles not important } \\
\text { enough to be clarified and } \\
\text { reinforced by institutional } \\
\text { behavior } \\
\text { Academic faculty perception } \\
\text { of librarians as support staff }\end{array}$ & $\begin{array}{l}\text { Institution/Library } \\
\text { Administrators }\end{array}$ & $\begin{array}{l}\text { Promote library's contribution to the overall mission of the } \\
\text { academic institution, especially in university's strategic } \\
\text { planning }\end{array}$ \\
\hline
\end{tabular}




\section{Notes}

1. W.E. Henry, "Academic Standing of College Library Assistants and Their Relation to the Carnegie Foundation," Bulletin of the American Library Association 5, no. 4 (1911): 260.

2. Ibid.

3. Catherine Coker, Wyoma vanDuinkerken, and Stephen Bales, "Seeking Full Citizenship: A Defense of Tenure Faculty Status for Librarians," College \& Research Libraries 71, no. 5 (2010): 406-20.

4. The ACRL has also published "Guidelines for Academic Librarians without Faculty Status" to support the "rights, privileges, and responsibilities" of librarians employed by institutions that do not offer faculty status to librarians, available online at www.ala.org/acrl/standards/ guidelinesacademic [accessed 20 March 2014].

5. Association of College and Research Libraries, Association of American Colleges and Universities, and American Association of University Professors, "Joint Statement on Faculty Status of College and University Librarians," 2012.

6. Lee G. Bolman and Terrence E. Deal, Reframing Organizations: Artistry, Choice, and Leadership, 4th ed. The Jossey-Bass Business \& Management Series (San Francisco: Jossey-Bass, 2008).

7. To differentiate them from academic librarians who have faculty status, throughout the paper we use the phrase "disciplinary faculty" to refer to classroom/teaching/regular faculty.

8. Lee Bolman, "Research Using or Influenced by Bolman \& Deal's Four Frames," available online at www.leebolman.com/four_frame_research.htm [accessed 20 March 2014].

9. See Felix T. Chu, "Framing Reference Encounters," RQ 36, no. 1 (1996); Gisela von Dran, "Human Resources and Leadership Strategies for Libraries in Transition," Library Administration E Management 19, no. 4 (2005): 177-84.; Zhixian Yi, "Conducting Meetings in the Change Process: Approaches of Academic Library Directors in the United States," Library Management 33, no. 1/2 (2012): 22-35.

10. Bolman and Deal, Reframing Organizations.

11. Henry Mintzberg, The Structuring of Organizations: A Synthesis of the Research (Englewood Cliffs, N.J. : Prentice-Hall, 1979), 19-21.

12. Bolman and Deal, Reframing Organizations, 82.

13. Ibid., 349-51.

14. Ibid., 301.

15. Mintzberg, Structuring of Organizations, 360.

16. Henry Mintzberg, Structure in Fives: Designing Effective Organizations (Englewood Cliffs, N.J.: Prentice-Hall, 1983), 197.

17. Henry Mintzberg, "Structure in 5's: A Synthesis of the Research on Organization Design," Management Science 26, no. 3 (1980): 334.

18. George D. Kuh and Elizabeth J. Whitt, The Invisible Tapestry: Culture in American Colleges and Universities, Ashe-Eric Higher Education Report (Washington, D.C.: Association for the Study of Higher Education, 1988), 76.

19. Lars Christiansen, Mindy Stombler, and Lyn Thaxton, "A Report on Librarian-Faculty Relations from a Sociological Perspective," Journal of Academic Librarianship 30, no. 2 (2004): 118.

20. U.S. Department of Education, National Center for Education Statistics, "Full-Time and Part-Time Faculty and Instructional Staff in Degree-Granting Institutions, by Level and Control of Institution and Selected Characteristics: Fall 1992, Fall 1998, and Fall 2003," from National Study of Postsecondary Faculty, 2009, reprinted in Digest of Education Statistics (2012): 390.

21. Mary K. Bolin, "Librarian Status at U.S. Research Universities: Extending the Typology," Journal of Academic Librarianship 34, no. 5 (2008): 416-24.

22. Christiansen et al., "A Report on Librarian-Faculty Relations," 118.

23. Paul Alan Wyss, "Library School Faculty Member Perceptions Regarding Faculty Status for Academic Librarians," College \& Research Libraries 71, no. 4 (2010): 377.

24. Lee G. Bolman and Terrence E. Deal, "Leadership and Management Effectiveness: A Multi-Frame, Multi-Sector Analysis," Human Resource Management 30, no. 4 (1991): 511.

25. Bolman and Deal, Reframing Organizations, 142.

26. Kuh and Whitt, The Invisible Tapestry, 76.

27. Bolman and Deal, Reframing Organizations, 142.

28. Bolman and Deal, "Leadership and Management Effectiveness," 511- -12.

29. Mintzberg, Structure in 5's, 334.

30. Orvin Lee Shiflett, The Origins of American Academic Librarianship (Norwood, N.J.: Ablex Publishing Corporation, 1981), 259.

31. Mary Biggs, "Sources of Tension and Conflict between Librarians and Faculty," Journal of Higher Education 52, no. 2 (1981): 185.

32. Ibid., 186. 
33. Jean A. Major, "Mature Librarians and the University Faculty: Factors Contributing to Librarians' Acceptance as Colleagues," College \& Research Libraries 54, no. 6 (1993): 464.

34. Christiansen, et al., "A Report on Librarian-Faculty Relations"; José A. Montelongo, Lynne Gamble, Navjit Brar, and Anita C. Hernandez, "Being a Librarian Isn't Enough: The Importance of a Nonlibrary Research Agenda for the Academic Librarian: A Case Study," College \& Undergraduate Libraries 17, no. 1 (2010): 2-19; Lan Shen, "Improving the Effectiveness of Librarian-Faculty Collaboration," Collaborative Librarianship 4, no. 1 (2012): 14-22.

35. Larry Hardesty, "Faculty Culture and Bibliographic Instruction: An Exploratory Analysis," Library Trends 44, no. 2 (1995): 339-67; Virginia Massey-Burzio, "From the Other Side of the Reference Desk: A Focus Group Study," Journal of Academic Librarianship 24, no. 3 (1998): 208-15.

36. Scott Walter, "Librarians as Teachers: A Qualitative Inquiry into Professional Identity," College \& Research Libraries 69, no. 1 (2008): 60.

37. Bolin, "Librarian Status at U.S Research Universities."

38. Rachel Applegate, "Deconstructing Faculty Status: Research and Assumptions," Journal of Academic Librarianship 19, no. 3 (1993): 158-64.

39. Bruce R. Kingma and Gillian M. McCombs, "The Opportunity Costs of Faculty Status for Academic Librarians," College \& Research Libraries 56, no. 3 (1995): 258.

40. Danielle Bodrero Hoggan, "Faculty Status for Librarians in Higher Education," portal: Libraries \& the Academy 3, no. 3 (2003): 431-45.

41. Corey M. Johnson and Elizabeth Blakesley Lindsay, "Why We Do What We Do: Exploring Priorities within Public Services Librarianship," portal: Libraries \& the Academy 6, no. 3 (2006): 363.

42. Christiansen et al., "A Report on Librarian-Faculty Relations."

43. Walter, "Librarians as Teachers," 60.

44. Ken Kempcke, "The Art of War for Librarians: Academic Culture, Curriculum Reform and Wisdom from Sun Tzu," portal: Libraries \& the Academy 2, no. 4 (2002): 533.

45. Todd Gilman and Thea Lindquist, "Academic Research Librarians with Subject Doctorates: Experiences and Perceptions, 1965-2006," portal: Libraries $\mathcal{E}$ the Academy 10, no. 4 (2010): 399.

46. Association of College and Research Libraries, "Statement on the Terminal Professional Degree for Academic Librarians," 2011.

47. Phillip J. Jones, "Academic Graduate Work in Academic Librarianship: Historicizing ACRL's Terminal Degree Statement," Journal of Academic Librarianship 24, no. 6 (1998): 437.

48. For discussions of acculturation, see Rush G. Miller, "The Influx of Ph.D.s into Librarianship: Intrusion or Transfusion?" College \& Research Libraries News 37 (1976): 158-65; M. Clark Barton and Thomas M. Gaughan, "Socialization of Library School Students: A Framework for Analysis of a Current Problem," Journal of Education for Librarianship 19, no. 4 (1979): 283-93; W.B. Mitchell and B. Morton, "On Becoming Faculty Librarians: Acculturation Problems and Remedies," College \& Research Libraries 53, no. 5 (1992): 379-92; Jean A. Major, "Mature Librarians and the University Faculty: Factors Contributing to Librarians' Acceptance as Colleagues," College \& Research Libraries 54, no. 6 (1993): 463-69; Jennifer Mayer and Lori J. Terrill, "Academic Librarians' Attitudes About Advanced-Subject Degrees," College \& Research Libraries 66, no. 1 (2005): 59-73; Jean-Pierre V. M. Hérubel, "Contextual Culture of the Master's Degree and the Decline of the M.L.S. Thesis: An Exploratory Review Essay," Libraries \& Culture 40, no. 1 (2005): 63-84; Jean-Pierre V. M. Hérubel, "Doctoral Degrees and the Academic Librarian, or, 'Is There a Doctor in the House?'” Indiana Libraries 25, no. 3 (2006): 42-44; Gilman and Lindquist, “Academic Research Librarians with Subject Doctorates." For discussions of improved subject knowledge, see Miller, "The Influx of Ph.D.s into Librarianship"; Deanna B. Marcum, "For University Librarians of the Future, the Degree in Library Science, by Itself, Will Not Be Sufficient," Chronicle of Higher Education, 1990, B1; Hérubel, "Doctoral Degrees and the Academic Librarian," 42-44; Gilman and Lindquist, "Academic Research Librarians with Subject Doctorates"; Wyss, "Library School Faculty Member Perceptions"; Deanna B. Marcum, "Do Librarians Need PhDs?" Information Outlook 16, no. 5 (2012): 33-35. Enhanced reputation is discussed by Bill Crowley, "Redefining the Status of the Librarian in Higher Education," College \& Research Libraries 57 (1996): 113-21; Mildred G. Jackson, "Image and Status: Academic Librarians and the New Professionalism," in Advances in Librarianship, ed. Elizabeth A. Chapman (Derby, U.K.: Emerald Publishing, 2000), 93-115; Mayer and Terrill, "Academic Librarians' Attitudes"; Gilman and Lindquist, "Academic Research Librarians with Subject Doctorates." For discussion of career development, see W. Bede Mitchell, "Response To: Academic Graduate Work in Academic Librarianship: Historicizing ACRL's Terminal Degree Statement," Journal of Academic Librarianship 24, no. 6 (1998): 444; Mayer and Terrill, "Academic Librarians' Attitudes."

49. Gilman and Lindquist, "Academic Research Librarians: Experiences and Perceptions," 403.

50. Mayer and Terrill, "Academic Librarians' Attitudes," 64.

51. Lili L. Luo, "Fusing Research into Practice: The Role of Research Methods Education," 
Library \& Information Science Research 33, no. 3 (Jul 2011): 191-201.

52. Laura Sare, Stephen Bales, and Bruce Neville, "New Academic Librarians and Their Perceptions of the Profession," portal: Libraries and the Academy 12, no. 2 (2012): 197.

53. Johnson and Lindsay, "Why We Do What We Do," 359.

54. Ibid., 363.

55. Ibid., 363.

56. Marie R. Kennedy and Kristine R. Brancolini, "Academic Librarian Research: A Survey of Attitudes, Involvement, and Perceived Capabilities," College \& Research Libraries 73, no. 5 (Sept. 2012): 438.

57. Bolman and Deal, Reframing Organizations, 16.

58. Hardesty, "Faculty Culture."

59. Wade R. Kotter, "Bridging the Great Divide: Improving Relations between Librarians and Classroom Faculty," Journal of Academic Librarianship 25, no. 4 (1999): 296.

60. Montelongo et al., "Being a Librarian," 3.

61. Kempcke, "The Art of War for Librarians," 529.

62. Pauline Wilson, "Librarians as Teachers: The Study of an Organization Fiction," The Library Quarterly 49, no. 2 (1979): 151.

63. Applegate, "Deconstructing Faculty Status," 158.

64. N.P. Barksdale, "Faculty Co-Operation with the Library Staff," Journal of Higher Education 13, no. 3 (1942): 146.

65. G.W. Thompson, "Faculty Recalcitrance about Bibliographic Instruction," in Bibliographic Instruction in Practice: A Tribute to the Legacy of Evan Ezra Farber, ed. L. Hardesty, J. Hastreiter, and D. Henderson (Ann Arbor, MI: Pierian Press, 1993), 103.

66. Wilson, "Librarians as Teachers," 154.

67. Blaise Cronin, "The Mother of All Myths," Library Journal 126, no. 3 (2001): 144.

68. Wyss, "Library School Faculty," 379-81.

69. Christiansen et al., "A Report on Librarian-Faculty Relations," 118.

70. Roger C. Schonfeld and Ross Housewright, "Faculty Survey 2009: Key Strategic Insights for Libraries, Publishers, and Societies" (Ithaka S+R, Apr. 7, 2010): 5, available online at www. ithaka.org/ithaka-s-r/research/faculty-surveys-2000-2009/faculty-survey-2009 [accessed 24 January 2013].

71. Markus Lücken and Bernd Simon, "Cognitive and Affective Experiences of Minority and Majority Members: The Role of Group Size, Status, and Power," Journal of Experimental Social Psychology 41, no. 4 (2005): 396.

72. Ibid., 405.

73. Ibid., 410.

74. Antonio J. Castro, "Themes in the Research on Preservice Teachers' Views of Cultural Diversity: Implications for Researching Millennial Preservice Teachers," Educational Researcher 39, no. 3 (2010): 198-210.

75. Kempcke, "The Art of War"; Gloria J. Leckie and Anne Fullerton, "Information Literacy in Science and Engineering Undergraduate Education: Faculty Attitudes and Pedagogical Practices," College \& Research Libraries 60, no. 1 (1999): 9.

76. This is the terminology that Catherine Coker, Wyoma vanDuinkerken, and Stephen Bales (among others) use to describe disciplinary faculty.

77. Donald E. Riggs, "Faculty Status for Librarians: Force-Fitting into an Inappropriate Mold or Not?" College \& Research Libraries 60, no. 4 (July 1999): 305.

78. W. Bede Mitchell and Mary Reichel, "Publish or Perish: A Dilemma for Academic Librarians?" College \& Research Libraries 60, no. 3 (1999): 232-43.

79. Ronit Bogler and Lya Kremer-Hayon, "The Socialization of Faculty Members to University Culture and Norms," Journal of Further and Higher Education 23, no. 1 (1999): 31-40.

80. William B. Badke, "Can't Get No Respect: Helping Faculty to Understand the Educational Power of Information Literacy," Reference Librarian 43, no. 89/90 (2005): 66.

81. Dorothea Salo, "Innkeeper at the Roach Motel," Library Trends 57, no. 2 (2008): 98-123.

82. Bolman and Deal, Reframing Organizations, 260.

83. Ibid., 259.

84. Ibid., 255.

85. Anna E. McEwan, "Do Metaphors Matter in Higher Education?" Journal of College and Character 8, no. 2 (2007): 1-8.

86. Deborah J. Grimes, "Centrality and the Academic Library," The University of Alabama, 1993; Deborah Jean Grimes, Academic Library Centrality: User Success through Service, Access, and Tradition. ACRL Publications in Librarianship, vol. 50 (Chicago: ACRL, 1998).

87. Beverly P. Lynch, Catherine Murray-Rust, Susan E. Parker, Deborah Turner, Diane Parr Walker, Frances C. Wilkinson, and Julia Zimmerman, "Attitudes of Presidents and Provosts on 
the University Library," College \& Research Libraries 68, no. 3 (2007): 218.

88. Ibid., 226.

89. William J. Goode, "The Librarian: From Occupation to Profession?" The Library Quarterly 31, no. 4 (1961): 316.

90. Wilson, "Librarians as Teachers," 151.

91. Gilman and Lindquist, "Academic Research Librarians: Experiences and Perceptions"; Christiansen et al., "A Report on Librarian-Faculty Relations," 117; Mayer and Terrill, "Academic Librarians' Attitudes."

92. Peter Hernon, Ronald R. Powell, and Arthur P. Young, "University Library Directors in the Association of Research Libraries: The Next Generation, Part One," College \& Research Libraries 62, no. 2 (2001): 116-45.

93. Mitchell and Morton, "On Becoming Faculty Librarians," 383.

94. Major, "Mature Librarians," 467.

95. Mildred G. Jackson, "Image and Status: Academic Librarians and the New Professionalism," in Advances in Librarianship, ed. Elizabeth A. Chapman (Derby, U.K.: Emerald Publishing, 2000), 93-115; D. Montanelli and P. Stenstrom, "The Benefits of Research for Academic Librarians and the Institutions They Serve," College \& Research Libraries 47 (1986): 482-85; Montelongo et al., "Being a Librarian."

96. Christiansen et al., "A Report on Librarian-Faculty Relations," 119.

97. Ibid., 120.

98. Lynch, "What We Now Know About Librarians."

99. Robyn Marschke, Sandra Laursen, Joyce McCarl Nielsen, and Patricia Rankin, “Demographic Inertia Revisited: An Immodest Proposal to Achieve Equitable Gender Representation among Faculty in Higher Education," Journal of Higher Education 78, no. 1 (2007): 1.

100. Wilson, "Librarians as Teachers," 150.

101. See Sare et al., "New Academic Librarians," 181; Shifra Baruchson-Arbib and Sherry Mendelovitz, "A Study of Israeli Library and Information Science Students' Perceptions of Their Profession," Libri 54, no. 2 (2004): 82-97.

102. Maura Seale, "Old Maids, Policeman, and Social Rejects: Mass Media Representations and Public Perceptions of Librarians," Electronic Journal of Academic \& Special Librarianship 9, no. 1 (2008): unpaged.

103. Kempcke, "The Art of War," 530.

104. Kenneth E. Carpenter, "The Librarian-Scholar," Journal of Academic Librarianship 23, no. 5 (1997): 399.

105. Wilson, "Librarians as Teachers," 173.

106. Walter, "Librarians as Teachers," 59.

107. Wyss, "Library School Faculty Member Perceptions"; Robert Perret and Nancy J. Young, "Economic Status of Academic Librarians," portal: Libraries and the Academy 11, no. 2 (2011): 703-15.

108. Lücken and Simon, "Cognitive and Affective Experiences," 410.

109. Kempcke, "The Art of War."

110. Larry R. Oberg, Mary Kay Schleiter, and Michale Van Houten, "Faculty Perceptions of Librarians at Albion College: Status, Role, Contribution and Contracts," College \& Research Libraries 50, no. 2 (1989): 215-30; Ada M. Ducas and Nicole Michaud-Oystryk, "Toward a New Venture: Building Partnerships with Faculty," College \& Research Libraries 65, no. 4 (2004): 334-48.

111. Kina S. Mallard, "The Soul of Scholarship," New Directions for Teaching and Learning 2002, no. 90 (2002): 63.

112. Julie Arendt and Megan Lotts, “What Liaisons Say About Themselves and What Faculty Say About Their Liaisons: A U.S. Survey," portal: Libraries and the Academy 12, no. 2 (2012): 155-77.

113. Kempcke, "The Art of War," 534.

114. Hardesty, "Faculty Culture"; Montelongo et al., "Being a Librarian," 2.

115. Kennedy and Brancolini, "Academic Librarian Research."

116. Robert Ferguson Munn and R. F. Munn, "Bottomless Pit, or the Academic Library as Viewed from the Administration Building," College \& Research Libraries 29 (1968): 51-54.

117. Don Chaney, Elizabeth Chaney, and James Eddy, "Context of Distance Learning Programs in Higher Education: Five Enabling Assumptions," Online Journal of Distance Learning Administration 13, no. 4 (2010): unpaged.

118. Carol Tenopir, "Measuring the Value of the Academic Library: Return on Investment and Other Value Measures," Serials Librarian 58, no. 1-4 (2010): 39-48.

119. The Lib-Value Project and the ACRL's Value Initiative are currently engaged in developing value and impact assessment models and other resources for academic libraries. 